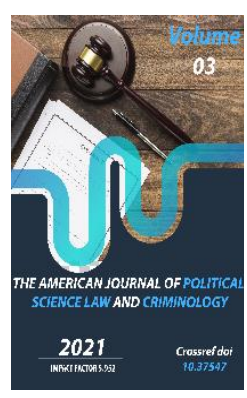

\title{
Experience Of Uzbekistan And Prospects For Development In Improving The Mechanisms Of Public Control
}

\author{
Usmonov Otabek Odilbek Ugli \\ Master Student, Department Public Administration Law, Tashkent State University Of Law, \\ Ministry Of Justice Of The Republic Of Uzbekistan
}

Copyright: Original content from this work may be used under the terms of the creative commons attributes 4.0 licence.

\section{ABSTRACT}

This article analyzes the content and essence of public control and its role, importance and necessity in the prevention of corruption, its organizational and legal basis and prospects. The legal experience of Uzbekistan in introducing strong social aspects of public control to fight against corruption has been studied. Comments were made on the development of state bodies and the mechanisms of public control in it, and grows of democratic factors. Specific suggestions and recommendations have been made on some of the problems in this area and ways to solve them.

\section{KEYWORDS}

Prevention of corruption, public control, objects and subjects of public control, forms of public control.

\section{INTRODUCTION}

The Republic of Uzbekistan is currently experiencing a unique period of development.
We can see new reforms in our state in all spheres. It is especially distinguished by the 
rule of law, law enforcement, the role and active participation of citizens in them, its vitality in the field of legal practice and its equal impact on all, and occupies a special place. In each state, laws are important in regulating the social and political relations of citizens. The President of the Republic of Uzbekistan Sh.M.Mirziyoev in his Address to the Oliy Majlis on January 24, 2020 stated that "The movement towards democratic reforms is the only and the right path for us." After all, all the new normative document defines the capabilities of any industry, and on the other hand imposes certain restrictions. At present, we can see that in the reforms of the social sphere in our country, many opportunities have been created for public control over the definition of the principles of order, and it is developing. The period of independence has a special significance in the history of statehood of the Republic of Uzbekistan. In the process of building the rule of law and the formation of civil society, the selection of its promising directions, the development of civil society institutions, their analytical, critical review, further intensification of these institutions, including strengthening public control over the activities of civil society institutions The issue is topical. In our country, we can see that the fight against corruption has developed rapidly in the reforms of the social sphere, in the definition of its principles of order, and in this regard, many opportunities have been created for public scrutiny. In this regard, the Decree of the President of the Republic of Uzbekistan dated June 29, 2020 No. 6013 "On additional measures to improve the anti-corruption system in the Republic of Uzbekistan" is of great importance. This decree defines the establishment of the Anti-Corruption Agency and its functions. It was one of the first organizations in the Republic of Uzbekistan established on the basis of international standards and recommendations of international research institutes. The decree also provides for the establishment and composition of the National "Anti-Corruption Council". In the fight against corruption, the principles of regulation and accountability of public authorities are being adapted to democratic principles in all respects.

We believe that the rapid development of public control in Uzbekistan is the responsibility of the executive bodies and their leaders to the people's legislature, the Oliy Majlis, which is considered necessary, and its legal framework is being formed and existing norms are being amended. We can see that a full-blooded transition to democracy has begun, especially through the Prime Minister and the General Procurator, who report annually to Oliy Majlis on their work and responsibilities. These cases mean that systematic and large-scale work on public control is being carried out. The concept of public oversight was largely introduced in 2014 with the introduction of amendments to our Constitution on public oversight. Later, many normative legal acts dedicated to public control or regulating its means were created, which we will discuss in more detail later. Public hearings are a special form of public oversight, in which officials report to the public on their authority. At the same time, the development of mechanisms for improving public control is based on the following aspects: In our opinion, the study of aspects that serve to improve public control in Uzbekistan and the development of proposals for its introduction into national practice is of great importance in public control. This is determined to some extent by the fact that 
citizens are free to express their views on their lives, issues and problems, to demand their legitimate interests and that there are no obstacles, and that citizens play an active role in resolving social relations. The stronger and more influential the public control in the society, the more development factors will be provided in the society and the cases of corruption will never be tolerated, because the stronger the society and the more developed the public control, the more illegal actions citizens do not allow. and realize the negative impact on their lives, their role in society.

To determine the main aspect of strong public control and the effective aspects of the mechanism, the following should be done. (instead of a proposal!)

- Creation of a new ideology of public control over our citizens, especially the younger generation, and the creation of a nationwide system of collecting views.

- Development of specific measures and a draft law of a recommendatory nature on the existing norms in the field of public control and ways to improve them.

- Analysis of ways to develop national experience in the field of public control and ensure the active role of citizens and other social and legal institutions in it.

- Adequate study of the areas of public control in international practice, the creation of a single system for analytical, critical review and its adoption in accordance with our statehood, social policy.

- It is necessary to interpret the international experience and national practice, to develop a system of conclusions based on a comprehensive study of proposals and developments, public opinion, proposals and to develop public control, to determine its prospects, to study and analyze in depth new social aspects. It is necessary to study the existing obstacles in the way and develop an effective program of measures to overcome them and regulate it from a normative point of view.

- A complete theoretical justification of the aspects and problems that are facing scientific public scrutiny and may occur in the future.

- To identify and develop proposals for the development of civil society in our country, public control over its effective construction, strengthening its regulatory framework and the development of new ones.

The current XXI century is a period of new technologies, new social relations. As our lives develop, it will become a vitally important to create new norms, to create mechanisms to regulate them, to improve them, to implement international experiences. Public oversight is an important condition for the development of civil society. The basis of civil society is determined mainly by the factors of public control, the rule of law in the country and the role of the population in it, the degree of influence. In this regard, its legal basis can be seen in the Law of the Republic of Uzbekistan dated April 12, 2018 No. 474 "On Public Control". This law consists of 21 articles and defines the place of public control in almost all social aspects. In particular, the law provides for the "study of public opinion", which sets out the rules for the organization of all important social aspects. On this basis, in order to study public opinion, suggestions and complaints on the legislation, the portal regulation.gov.uz was created at the initiative of the government and at the suggestion of the 
public, and its legal basis was determined. At present, this portal plays an important role in defining the role of the public in our national legislative system, public control and is one of our great achievements in the field of public control.

Primary norms of the Republic of Uzbekistan on public control:

- Law of the Republic of Uzbekistan dated December 9, 2015 No. 395 "On Egovernment".

- Law of the Republic of Uzbekistan dated April 12, 2018 No. 474 "On public control". This law consists of 21 articles and is the basis for regulating this area.

- Decree of the President of the Republic of Uzbekistan dated January 9, 2019 No PF5618 "On radical improvement of the system of raising legal awareness and legal culture in society." (Concept)

At present, the specificity of e-government in international practice is one of the most important sectors in strengthening public control, ensuring its effective mechanisms, and the media play an important role in this.

In the world experience, almost all areas are covered by the e-government network. We can see the specific public control of e-government in our country being introduced in the media (hereinafter referred to as the media). In this regard, the Law of the Republic of Uzbekistan dated December 9, 2015 No. 395 "On Egovernment" is of great importance. The media has been responding quickly to any event of social significance, providing a unique public scrutiny.

Public control can be exercised not only by citizens, but also by citizens' self-government bodies, legal organizations, the media. In a few words, we must take the specifics of the international experience of developed countries and promote it in a way that suits our national social environment. At the same time, of course, our national values and Uzbek culture play a key role. As a new social spirit, a new worldview, the principle of intolerance based on justice are formed and developed in our society, in our people, we will move forward to a new era, to the construction of civil society. To do this, our citizens living on this land must live a new life and a deep sense of social responsibility in building it together. Public control and its forms of implementation, public opinion is its practical aspects, aspects of international experience of public control and their application in terms of national principles, and all social relations that cover this area. In today's developed world, public control is the basis of national practice and international experience, the specific aspects and existing problems associated with the creation and improvement of legislative systems based on the Constitution. Another aspect of strengthening public control is that the Concept on Radical Improvement of the System of Raising Legal Awareness and Legal Culture in the Society states. In general, the aspects of legal ideology, legal consciousness and public control within them, which should be formed in the younger generation, are also socially relevant. It is also necessary to consistently organize the existing problems in this area, and we would suggest them to create a new system for finding solutions and developing recommendations based on the conditions of Uzbekistan. The basis for the development of new specific proposals in the field of public control, including the study of active proposals of citizens and the selection and analysis of 
experiences that have been found to be effective, and on this basis "Create a model of Uzbek public control ". To do this, first of all, the country must have democratic and diversity of opinion, freedom, mutually beneficial cooperation between government agencies and the people. No matter how hard the law enforcement agencies try, we will not be able to organize an effective fight against this scourge unless our people are intolerant of this abomination and establish effective public control. It is also clear from the report of the President that one of the most effective ways to combat corruption is public control. At the same time, it is necessary to strengthen public control and create its mechanisms, and, above all, to support the process of government agencies and their immediate superiors. Our people must understand that this situation is one of the most important factors in improving society and development. It would be said that the more public control we develop, the more we will continue to build civil society. Public control acts as a powerful "weapon" in the hands of the people.

As our society and people develop a new social spirit, a new worldview, the principle of intolerance based on justice, we will move closer to the new era of building a new "Civil Society". live with a sense of responsibility for building a socially prosperous civil society. President Sh.M.Mirziyoev, as the head of the reformist state, is doing a great job here. We believe that our people (all patriots who feel involved in the development of this country) must unite and work for the development of unity and solidarity of the Uzbek people, and contribute to the vital reforms of the head of our state. We believe that this will be a new period in the development of our statehood and will have a special place in our history and become one of the most recent developments, a period of legal reforms.

\section{REFERENCES}

1. The Constitution of the Republic of Uzbekistan. Tashkent "Uzbekistan" 2019.

2. Address of the President of the Republic of Uzbekistan Sh.M.Mirziyoev to the Oliy Majlis of January 24, 2020.Press service of the President of the Republic of Uzbekistan http://press-servise.uz

3. Law of the Republic of Uzbekistan dated December 9, 2015 No. 395 "On eGovernment". // National Database of Legislation, 10.08.2020 y. https://lex.uz.

4. Law of the Republic of Uzbekistan dated April 12, 2018 No. 474 "On public control". // National Database of Legislation, 10.08.2020 y. https://lex.uz.

5. Decree of the President of the Republic of Uzbekistan No. PF-5618 of January 9, 2019 "On radical improvement of the system of raising legal awareness and legal culture in society." (Concept) // National Database of Legislation, 10.08.2020. https://lex.uz.

6. Law of the Republic of Uzbekistan "On amendments and additions to some legislative acts of the Republic of Uzbekistan in connection with the further improvement of legislative and parliamentary control processes" // National Database of Legislation, 10.08.2020. https://lex.uz.

7. Draft Resolution of the President of the Republic of Uzbekistan "On measures to radically improve the system of use of official vehicles in public authorities and administration" // Portal for 
Doi: https://doi.org/10.37547/tajpslc/Volume03Issue03-19

discussion of regulatory legal acts of the Republic of Uzbekistan. (№ ID20761) https://regulation.gov.uz.

8. Zulfiqorov Sh.X. Participation of deputies and the general public in the preparation of draft laws and control over the implementation of laws in our country // Bulletin of legal sciences Vestnik yuridicheskix nauk / Review of law sciences. https: //doi.org10.34920/rls.1.2020.22-26.

9. Portal for discussion of normative legal acts of the Republic of Uzbekistan. https://regulation.gov.uz 